\title{
Glacial retreat in the Amundsen Sea sector, West Antarctica - first cosmogenic evidence from central Pine Island Bay and the Kohler
}

\section{Range}

\author{
Julia Lindow ${ }^{\text {a, * }}$, Marion Castex ${ }^{\text {a }}$, Hella Wittmann ${ }^{\mathrm{b}}$, Joanne S. Johnson ${ }^{\mathrm{c}}$, Frank Lisker ${ }^{\mathrm{a}}$, \\ Karsten Gohl ${ }^{\mathrm{d}}$, Cornelia Spiegel ${ }^{\mathrm{a}}$ \\ a Department of Geosciences, University of Bremen, Bremen, Germany \\ ${ }^{\mathrm{b}}$ Helmholtz-Centre Potsdam - German Research Centre for Geosciences (GFZ), Potsdam, Germany \\ ${ }^{\mathrm{c}}$ British Antarctic Survey, Natural Environment Research Council, High Cross, Madingley Road, Cambridge CB3 OET, UK \\ d Alfred Wegener Institute, Helmholtz-Centre for Polar and Marine Research (AWI), Bremerhaven, Germany
}

\section{A R T I C L E I N F O}

\section{Article history:}

Received 14 February 2014

Received in revised form

13 May 2014

Accepted 15 May 2014

Available online 4 July 2014

\section{Keywords:}

Surface exposure dating

Amundsen Sea Embayment

West Antarctic Ice Sheet

Deglaciation history

Holocene

Pine Island Bay

Kohler Range

Cosmogenic isotopes

Glacial retreat

\begin{abstract}
A B S T R A C T
The Amundsen Sea Embayment of West Antarctica hosts one of the most rapidly changing sectors of the West Antarctic Ice Sheet. With the fastest-flowing ice streams in Antarctica, the region around Pine Island Bay is characterized by rapid ice-sheet thinning and grounding-line retreat. Published surfaceexposure data are limited to a few isolated nunataks making it difficult to assess the long-term deglacial history of the area. To address this, we correlate existing records of lateral ice-stream retreat from marine sediment cores with onshore glacial thinning in two key areas of eastern Marie Byrd Land: the Kohler Range and Pine Island Bay. Our ${ }^{10} \mathrm{Be}$ surface-exposure ages are the first from the isolated Kohler Range and show that the nunataks there became ice-free between 8.6 and $12.6 \mathrm{ka}$. This implies a minimum long-term average thinning rate of $3.3 \pm 0.3 \mathrm{~cm} / \mathrm{yr}$, which is one order of magnitude lower than recent rates based on satellite data. We also present pre- to early Holocene ${ }^{10} \mathrm{Be}$ surface-exposure ages from two islands located approximately $80 \mathrm{~km}$ downstream of the Pine Island Glacier ice-shelf front to constrain the lateral deglacial history in the Pine Island Bay area. This study provides insight into the significance of local ice sheet variations and suggests that the post-LGM history in the Amundsen Sea sector was characterized by glacial thinning as well as lateral retreat in pre- to early Holocene times.
\end{abstract}

() 2014 Elsevier Ltd. All rights reserved.

\section{Introduction and background}

For more than 40 years the concern of a rapid disintegration of the West Antarctic Ice Sheet (WAIS) has motivated studies on understanding the past, present and future behavior of the WAIS (Mercer, 1978). Although the WAIS holds only 10\% of the Antarctic ice volume, its collapse would contribute about $3.3 \mathrm{~m}$ of eustatic sea-level rise, of which the Amundsen Sea sector alone would contribute $1.2 \mathrm{~m}$ (Bamber et al., 2009b; Fretwell et al., 2013). At present, the Amundsen sector of WAIS is characterized by accelerated discharge (e.g. Rignot et al., 2008), rapid thinning along the ice-sheet margins, and fast grounding-line retreat (e.g. Pritchard et al., 2009; Joughin et al., 2010). Not only have the past two decades been marked by accelerated thinning, recent modeling

\footnotetext{
* Corresponding author.

E-mail address: lindow.julia@googlemail.com (J. Lindow).
}

studies suggest that Pine Island Glacier in particular may already be in an unstable condition (Favier et al., 2014). Those studies indicate that the average mass loss could multiply five times over the next 20 years, reaching approximately $100 \mathrm{Gt} / \mathrm{yr}$.

Paleo-data, such as exposure ages from cosmogenic nuclide concentrations, play an important role in testing and refining existing ice-sheet models and thereby enable more reliable estimation of future ice-sheet evolution. This is essential for predicting the timing and magnitude of future sea level rise. Several marine-geological and geophysical studies have refined our understanding of the post-LGM (Last Glacial Maximum; ca 23-19 ka) glacial history in the Amundsen Sea Embayment (Fig. 1). Subglacial bedforms and analyses of seasonally openmarine sediments from the outer shelf indicate that the grounded ice margin was close to the shelf break at the LGM (e.g. Graham et al., 2010; Kirshner et al., 2012; Larter et al., 2014, and references therein). There are also indications that the groundingline had already retreated close to its present-day position by the 


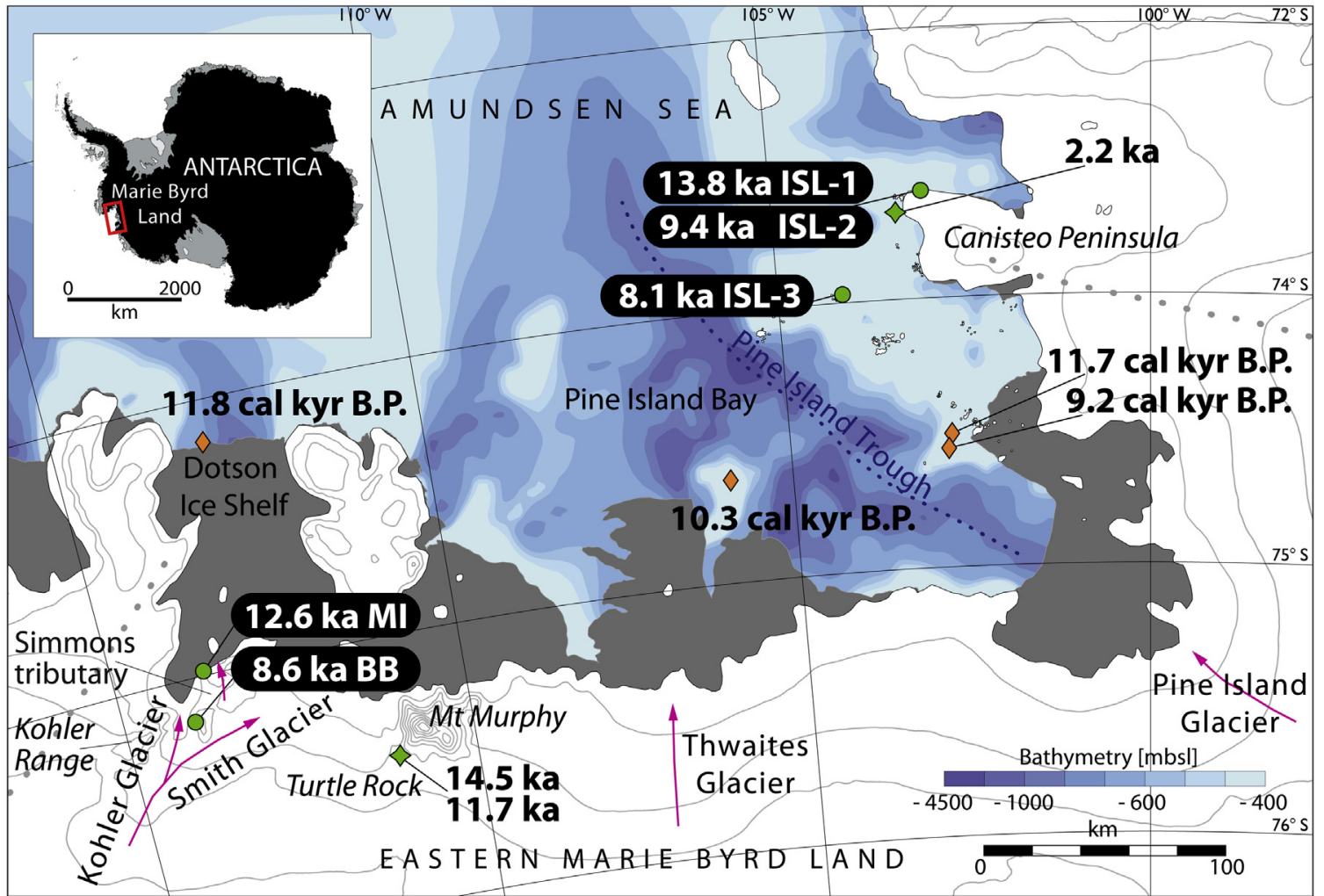

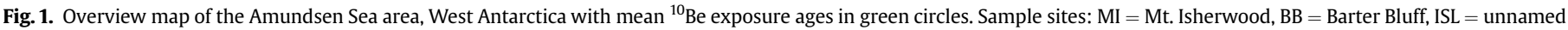

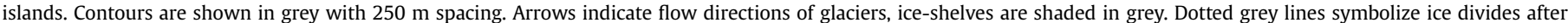

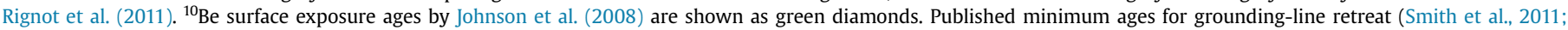

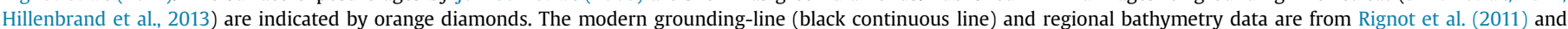

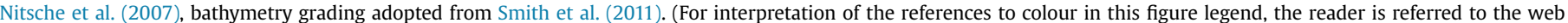
version of this article.)

early Holocene (Hillenbrand et al., 2013). In contrast, terrestrial studies of deglaciation of coastal Marie Byrd Land are lacking: the only existing studies are those of Stone et al. (2003) and Johnson et al. (2008), who used surface-exposure dating to determine onshore post-LGM ice-sheet evolution in the this area. Both studies obtained similar average thinning rates for the early to late Holocene $(2.5-9 \mathrm{~cm} / \mathrm{yr})$. For western Marie Byrd Land (i.e. $\sim 1000 \mathrm{~km}$ away from the Amundsen Sea sector), Stone et al. (2003) showed that thinning continued throughout the Holocene at a similar rate. Johnson et al. (2008) reported surface exposure ages of $14.5 \pm 1.2 \mathrm{ka}(700 \mathrm{~m})$ and $11.7 \pm 1.2 \mathrm{ka}(630 \mathrm{~m})$ for eastern Marie Byrd Land (Turtle Rock, next to Mt. Murphy; Fig. 1), and one age for an unnamed island among the Lindsay Islands of $2.2 \pm 0.2 \mathrm{ka}$ (close to sea level; Fig. 1). They inferred that deglaciation in the Amundsen Sea sector was underway by at least $14.5 \mathrm{ka}$, and provided a long-term thinning rate for Turtle Rock that is ten times slower compared to modern satellite measurements along adjacent ice streams $(2.3 \pm 0.2 \mathrm{~cm} / \mathrm{yr}$ versus $>30 \mathrm{~cm} / \mathrm{yr}$; Johnson et al., 2008; Pritchard et al., 2009). To understand whether the difference between long-term and modern ice-sheet thinning rates results from short-term climate variation or represents the final stage of internal ice dynamical change, more millennial-scale records are needed (Larter et al., 2014, and references therein). Here we report surface exposure data for the Kohler Range and Pine Island Bay to improve reconstructions on the post-LGM glacial history of the Amundsen Sea sector of the WAIS, provide additional age constraints for future ice-sheet models, and address the relation of lateral retreat and glacial thinning by correlating onshore and offshore terrestrial data.

\section{Setting}

\subsection{The West Antarctic Ice Sheet}

The WAIS comprises the area between longitudes $180^{\circ}$ and $60^{\circ} \mathrm{W}$. Major parts are grounded on one of the world's largest continental rifts, and more than 1500 m below sea level in many areas (e.g. LeMasurier, 2008; LeMasurier, 2008; Bingham et al., 2012; Fretwell et al., 2013). This unique configuration makes the WAIS a marine-based ice-sheet, and thereby especially vulnerable to changes in ocean temperature and prone to collapsing (e.g. Mercer, 1978; Joughin and Alley, 2011; Favier et al., 2014). In addition, the influence on the ice-sheet dynamics of underlying tectonic structures, seen in bathymetry images (e.g. Nitsche et al., 2013) and geophysical mapping (e.g. Gohl et al., 2013a, 2013b), is still not fully understood.

The WAIS is separated into well-defined drainage sectors following the satellite-borne remote sensing data from Bamber et al. (2009a). Of interest for this study is the 'Amundsen sector' which is defined by four ice divides and covers a combined area of 417,000 km² (Larter et al., 2014; references therein; Fig. 1). According to Rignot et al. (2008), the Amundsen sector contributes about $37 \%$ of the entire outflow from WAIS, whereas Pine Island Glacier alone is responsible for $20 \%$, and the mass loss is increasing (Shepherd et al., 2004). Because this sector is making a dominant contribution to sea level rise at present, it is critical that we understand the longer-term (millennial-scale) glacial history of the glaciers which drain it (mainly, Kohler, Smith, Thwaites, and Pine Island Glacier; Shepherd and Wingham, 2007, Fig. 1). During the 
last decades, satellite-borne radar, altimetry and interferometry data revealed that the flow velocity of the Pine Island and Smith Glaciers (Fig. 1) sped up about $42 \%$ and $83 \%$, respectively, within ten years (Rignot, 2008). The flow of the adjacent Kohler Glacier, which is buttressed by the Dotson Ice Shelf, accelerated $10-50 \%$ between 1996 and 2005 (Rignot, 2006).

\subsection{The Kohler Range}

The Kohler Range is a coast-proximal mountain chain striking $\mathrm{NE}-\mathrm{SW}$ with a length of $\sim 70 \mathrm{~km}$. Its two ice-covered plateaus have an average elevation of $500 \mathrm{~m}$ a.s.l., but rise above $900 \mathrm{~m}$ a.s.l. in the highest parts. The Kohler Glacier (Fig. 1) cuts between the plateaus in a $\mathrm{N}-\mathrm{S}$ direction and is a distributary of the Smith Glacier to the East (Fig. 1). A deep trough beneath the glacier can be seen in subglacial bathymetry (Fig. 4; Fretwell et al., 2013), and glacial erosion has created steep flanks. The majority of the Kohler Range is covered by ice, with the exception of a few nunataks including Barter Bluff and Mount Isherwood (e.g. Fig. 2). These nunataks are characterized by flat terrain with rounded coarse-grained erratic boulders of granitic composition perched on bedrock surfaces (Fig. 2).

\subsection{Pine Island Bay}

Striking roughly NW-SE, Pine Island Bay is located at the southeastern end of the Amundsen Sea Embayment (Fig. 1). It measures $\sim 100 \mathrm{~km}$ across, is $\sim 200 \mathrm{~km}$ long and marks the calving grounds of the Pine Island Glacier. The bay is underlain by a deep trough which extends upstream beneath the Pine Island Glacier (Fig. 1). This feature is suggested to be a former - and maybe still active- arm of the West Antarctic Rift System (e.g. Bingham et al., 2012; Gohl et al., 2013a, 2013b). Several groups of low relief islands are situated in Pine Island Bay, the majority of which are aligned along the main axis of the rift arm and perpendicular to it. The islands generally rise no more than $50 \mathrm{~m}$ above sea level; only a few exceptions reach elevations above $100 \mathrm{~m}$ a.s.l.. The dominant bedrock lithology is coarse-grained granite often containing mafic xenoliths of varying sizes $(\mathrm{cm}-\mathrm{m})$ and partly cut by mafic dykes. In general, the bedrock surfaces bear striations and are rounded as a result of glacial erosion. They are also frost-shattered (Fig. 2). Erratics are rare and difficult to distinguish from misplaced bedrock since both are often composed of the same lithology.

\subsection{Accessibility}

Although crucial for understanding the changes of the WAIS, the Amundsen sector is one of the most challenging regions of Antarctica to reach and study from a logistical perspective as well as weather-wise. One of these difficulties is the high proportion of days with poor visibility making it unsafe for helicopter surveys or ground travel; this applies especially for coastal outcrops. Additionally, the lack of polar research stations in the near vicinity further complicates field campaigns. Hence we are the first since 1992 (SPRITE-Group and Boyer, 1992) to collect samples from the Kohler Range, and present the first constraints on deglaciation of the Kohler Glacier.

\section{Sampling}

We used cosmogenic ${ }^{10} \mathrm{Be}$-surface exposure dating to reconstruct the timing of glacial retreat (cf. Stone et al., 2003; Mackintosh et al., 2007) in the Amundsen Sea Embayment. Cruise ANT-XXVI/3 of research vessel Polarstern provided the opportunity for a helicopter supported onshore sampling campaign in Pine Island Bay and the Kohler Range. Two sampling strategies were applied in this study and sample sites have been chosen accordingly: 1) sampling along an iso-altitude profile to reconstruct glacial retreat; 2) collecting samples from different altitudes along one profile to calculate age-elevation relationships and reconstruct the long-term average thinning rate. Despite limited time for field work, we collected a total of five erratic boulders from altitudes between 457 and $737 \mathrm{~m}$ (a.s.l.) from two locations in the Kohler Range, and three bedrock samples from a horizontal profile across two unnamed

Field pictures, Pine Island Bay

$360^{\circ}$ degree, sample site, ISL-I (ISL-2 was sampled within $50 \mathrm{~m}$ ):

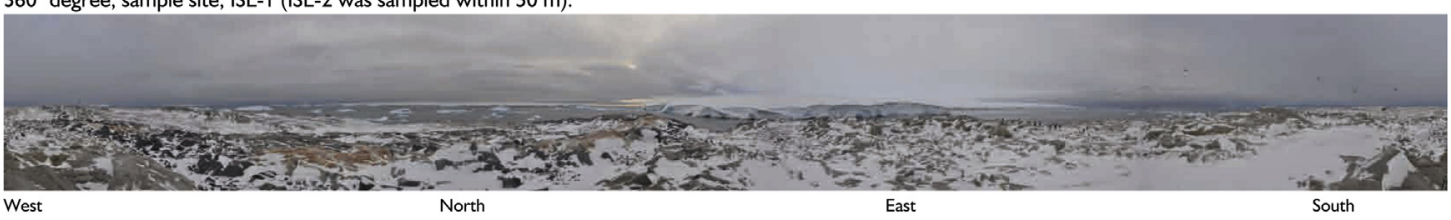

$360^{\circ}$ degree, sample site, ISL-3:

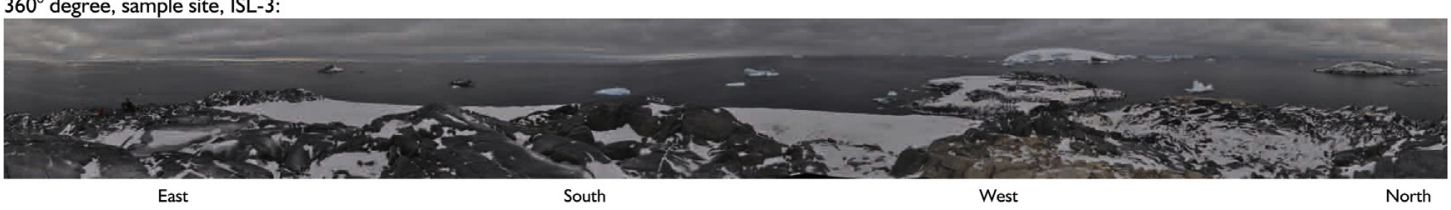

Field pictures, Kohler Range

Sample site, BB-2 (BB-I was sampled within $10 \mathrm{~m}$ ):
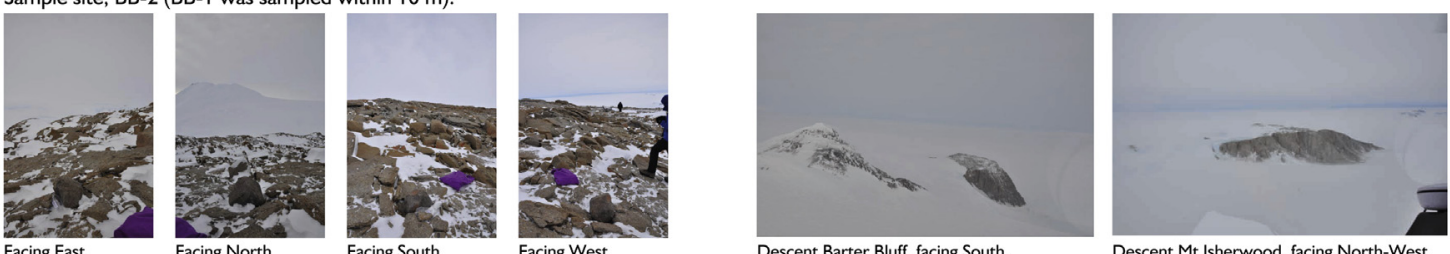

Fig. 2. Example field pictures showing sample locations and surrounding landscape of Pine Island Bay (top) and Kohler Range (bottom). 
islands in Pine Island Bay (Fig. 1). In the Kohler Range we sampled three erratics from an exposed plateau at Mount Isherwood (MI, $\sim 459 \mathrm{~m}$, two granites and one mylonite) and collected a pair of granite samples from the accessible flat of Barter Bluff (BB, $735 \mathrm{~m}$; Figs. 1 and 2). These nunataks are part of the same mountain range located adjacent to the Kohler Glacier and the Simmons tributary glacier (Fig. 1), respectively. In Pine Island Bay, we sampled bedrock from the most elevated points of two low-relief islands situated along Pine Island Trough and close to the coast (Figs. 1 and 2). To minimize potential shielding from cosmic rays at the sampling site due to snow coverage and/or geomorphic obstacles, samples were preferentially collected from flat and snow-free ground (Fig. 2).

For this study we used the CRONUS EARTH calculator v 2.2 (constant file v 2.2.1; Balco et al., 2008) to calculate the surface exposure ages, with the scaling scheme after Lal (1991) and Stone (2000) 'St', and the Antarctic ('ANT') pressure flag. No snow cover or erosion correction was applied (see section 5.1). Further details on samples, shielding estimates, ${ }^{10} \mathrm{Be}$ preparation, methods and analysis are provided in Appendix A - C and Table A.1 in the supplementary data (http://dx.doi.org/10.1016/j.quascirev.2014.05.010).

\section{Results}

Five exposure ages from the Kohler glacial system can be merged into two consistent age groups: $8.3 \pm 0.8$ and $8.7 \pm 0.9 \mathrm{ka}$ for Barter Bluff, and $12.4 \pm 1.2$ and $12.8 \pm 1.2$ ka for Mount Isherwood (Table 1, and Fig. 3). Because of this congruence we use mean ages of $8.6 \pm 0.8 \mathrm{ka}$ and $12.6 \pm 1.2 \mathrm{ka}$ for the respective nunataks. These results show that in the pre- to early Holocene, the ice sheet in the Kohler Range covered altitudes at least 733 to $457 \mathrm{~m}$ above sea level and thinned about 376 to $306 \mathrm{~m}$ since then. Sample MI-3 $(32.2 \pm 3.3 \mathrm{ka})$ is significantly older than the others (Table 1 , and Fig. 3). The most likely explanation for this older age is nuclide inheritance from a previous period of exposure (e.g. Johnson et al., 2008; White et al., 2011). Due to its potentially inherited age MI-3 is excluded from further interpretation.

Exposure ages from Pine Island Bay range from $8.1 \pm 0.8 \mathrm{ka}$ close to the Pine Island glacial trough to $9.4 \pm 0.9$ and $13.8 \pm 1.4 \mathrm{ka}$ from a second island near the coast (Fig. 1). There is a difference of $4.4 \mathrm{ka}$ between the exposure ages for ISL-1 and ISL-2, which cannot result purely from spatial variation: both samples are from the same island and the same bedrock, located less than $100 \mathrm{~m}$ apart with a difference in elevation of less than $10 \mathrm{~m}$. Even though there was no

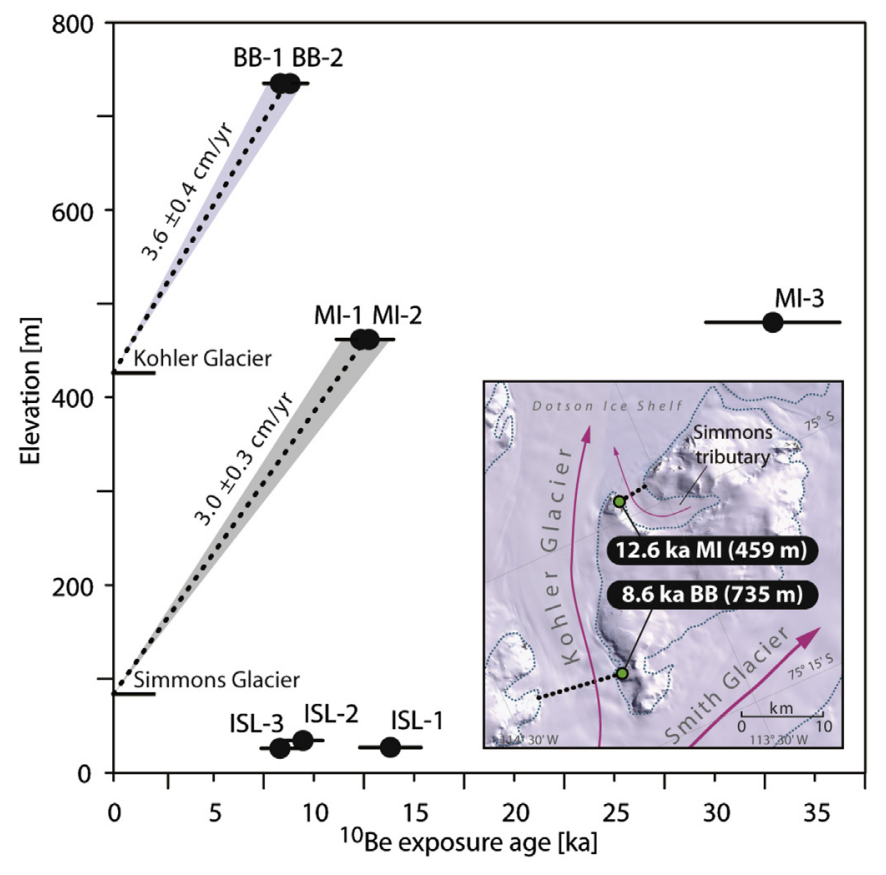

Fig. 3. ${ }^{10} \mathrm{Be}$ surface exposure ages and age-elevation relationships for the Kohler Range and the island samples from Pine Island Bay. MI = Mt. Isherwood, BB = Barter Bluff, $\mathrm{ISL}=$ unnamed islands. Dotted lines indicate the relationship between sample altitude, modern ice height and the corresponding long-term thinning rates of the Simmons and Kohler Glacier. Inset: The Kohler Range area with local glaciers (flow directions indicated by arrows). Mean ${ }^{10} \mathrm{Be}$ exposure ages are given at their sample sites: MI and $\mathrm{BB}$. Dotted black lines give the relation to adjacent modern ice surface for each sample site. The underlying satellite image is from Landsat Image Mosaic of Antarctica (LIMA; Bindschadler et al., 2008).

indication in the field, we cannot rule out minor nuclide inheritance from prior exposure. Accordingly, the age of ISL-1 may reflect more than the final glacial retreat. This uncertainty excludes ISL-1 from further interpretation, and since inheritance is less likely for the younger exposure age, we only consider the younger age of $9.4 \pm 0.9 \mathrm{ka}$, following similar approaches in previous studies (e.g. Stone et al., 2003; Mackintosh et al., 2007, 2014). Finally, the data resolution is too limited to allow predictions on maximum retreat ages, therefore the results presented here suggest a minimum time frame for surface exposure in the Amundsen Sea sector.

Table 1

Generic sample information.

\begin{tabular}{|c|c|c|c|c|c|c|c|c|c|c|c|}
\hline Sample & $\begin{array}{l}\text { Latitude } \\
\text { (DD) }{ }^{\mathrm{d}}\end{array}$ & $\begin{array}{l}\text { Longitude } \\
(\mathrm{DD})^{\mathrm{d}}\end{array}$ & $\begin{array}{l}\text { Elevation } \\
\text { (m a.s.l.) }\end{array}$ & $\begin{array}{l}{ }^{10} \text { Be concentration } \\
\text { (atoms } \mathrm{g}^{-1} \text { ) }\end{array}$ & $\begin{array}{l}\text { Analytical } \\
\text { uncertainty }^{\mathrm{b}} \\
(\%)\end{array}$ & $\begin{array}{l}\text { Production } \\
\text { rate (total) } \\
\left(\text { atoms } \mathrm{g}^{-1} \mathrm{a}^{-1} \text { ) }\right.\end{array}$ & $\begin{array}{l}\text { Amount of } \\
\text { material (g) }\end{array}$ & $\begin{array}{l}\text { Blank values } \\
\left(\mathrm{Be}^{10} / \mathrm{Be}^{9}[\mathrm{E}-12]\right)\end{array}$ & $\begin{array}{l}\text { Calculated } \\
\text { ages }^{\mathrm{a}} \\
\text { (yrs) }\end{array}$ & $\pm^{c}(\mathrm{yrs})$ & $\begin{array}{l}\text { Topographic } \\
\text { shielding }\end{array}$ \\
\hline \multicolumn{12}{|c|}{ Kohler Range } \\
\hline BB-1 & -75.159867 & -113.978367 & 737 & $94,388.184$ & 4.8 & 11.333 & 64.696 & 0.004 & 8350 & 830 & 0.99602 \\
\hline BB-2 & -75.159867 & -113.978367 & 733 & $98,693.736$ & 4.9 & 11.262 & 40.294 & 0.004 & 8784 & 878 & 0.99350 \\
\hline MI-1 & -74.983217 & -113.693833 & 460 & $108,243.549$ & 4.2 & 8.749 & 62.409 & 0.004 & 12,401 & 1200 & 0.99337 \\
\hline MI-2 & -74.983217 & -113.693833 & 460 & $111,746.596$ & 4.1 & 8.749 & 68.663 & 0.004 & 12,803 & 1234 & 0.99337 \\
\hline MI-3 & -74.983217 & -113.693833 & 457 & $278,823.842$ & 5.5 & 8.729 & 45.082 & 0.004 & 32,203 & 3338 & 0.99337 \\
\hline \multicolumn{12}{|c|}{ Pine Island Bay (PIB) } \\
\hline ISL-1 & -73.601700 & -103.016033 & 27 & $78,429.010$ & 4.8 & 5.705 & 177.378 & 0.006 & 13,794 & 1374 & 0.99998 \\
\hline ISL-2 & -73.602167 & -103.016850 & 34 & $53,833.099$ & 4.0 & 5.746 & 165.919 & 0.006 & 9386 & 900 & 0.99998 \\
\hline ISL-3 & -73.969317 & -104.134850 & 26 & $46,024.479$ & 5.5 & 5.695 & 103.073 & 0.006 & 8096 & 834 & 0.99936 \\
\hline
\end{tabular}

${ }^{a}$ Age: ages were calculated using the CRONUS EARTH calculator v 2.2 (constant file v 2.2.1, Balco et al., 2008) scaling scheme after Lal (1991) and Stone (2000) 'St', and the

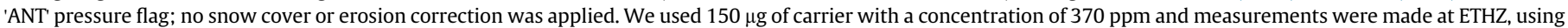
the AMS Standard: S2007N. For all samples we processed quartz from the upper $5 \mathrm{~cm}$ of material, and applied a density of $2.7 \mathrm{~g} / \mathrm{cm}^{3}$ during the age calculation.

b associated AMS measurement error.

c 'external error' after Balco et al. (2008) includes AMS measurement error, scaling scheme uncertainties, and uncertainties of scaling scheme input parameter (namely: reference production rate for spallation, production by muons, and site-specific atmospheric pressure).

d Reference datum: WGS 84/Antarctic Polar Stereographic. 


\section{Interpretation of surface exposure ages}

\subsection{Snow cover and topographic shielding}

Topographic shielding of all samples was minor to insignificant ( $\mathrm{S} \sim 0.99$, Table 1 ) because all samples were collected from nunatak flats overlooking the surrounding area. We did not apply any snow cover correction because per se a nunatak is an isolated, ice- and snow-free rock patch located in a glaciated area. Thus we assume the sampled nunataks in the Kohler Range have been covered only by snow of densities less than firn state (density $0.4-0.83 \mathrm{~g} / \mathrm{cm}^{3}$; Cuffey and Paterson, 2010, and references therein) since their first description (BB: mapped by U.S. Geological Survey and U.S. Navy air photos, 1959-1966; MI: was first photographed from aircraft of U.S. Navy Op Hjp, January 1947). Furthermore, from existing satellite images and the fact that the samples were collected in a snow-free period in March, we assume that the complete period between November and March was snow-free. Nonetheless, it remains uncertain how representative these relatively short-term observations are in respect to Holocene history. For a conservative estimate, we assume snow-cover during the remaining seven months from March to November (see also recommendation of Dunai, 2010; pages $89-90$ ). To induce an error of $>10 \%$ on the ages a snowoverburden of at least $1 \mathrm{~m}$ of wind-packed snow for each month is required (density of $0.35-0.4 \mathrm{~g} / \mathrm{cm}^{3}$; e.g. Cuffey and Paterson, 2010, and references therein). A seven months cover of pre-firn densities every year appears unlikely regarding the observed ice absence at the sample sites. Based on that, and to avoid the introduction of further uncertainties by a fully estimated snow-cover, we ultimately did not apply a correction for snow to our data.

\subsection{Pine Island Bay: nuclide inheritance vs. isostatic rebound}

The sampled islands are situated in a bay formed by glacial carving. They rise only a few meters above sea level. Therefore, it is possible that our exposure ages reflect exposure due to isostatic uplift, instead of (or combined with) glacial retreat. Locally, an average rebound of $0.63-0.66 \mathrm{~cm} / \mathrm{yr}$ through the Holocene is assumed based on recent models (relevant grid points from Whitehouse et al., 2012a, 2012b, and personal communication). This would result in 'rebound only ages' of $4.08 \pm 0.6$ to $5.47 \pm 0.7 \mathrm{ka}$ for the samples from below sea level up to their modern elevation. These ages however, do not agree with the ${ }^{10} \mathrm{Be}$ surface exposure ages observed from our samples, being about twice as old. To explain this discrepancy we suggest two possibilities:

i) Assuming the modeled rebound rates are reflecting the actual rebound history, this would imply a significant amount of excess ${ }^{10} \mathrm{Be}$ in the sampled bedrock. In glaciated areas there is no way to fully exclude the possibility of a complex exposure history with one or several previous exposures. Together with limited erosion as typical for cold-based glacial regimes, like West Antarctica since about $15 \mathrm{Ma}$, nuclide inheritance is a widespread phenomenon. Furthermore, the islands in Pine Island Bay are of very low relief. With the absence of high surface gradients there is also a possibility that abrasion energies have been too low to remove cosmogenic nuclides produced during earlier exposure. This option is supported by the $2.2 \mathrm{ka}{ }^{10} \mathrm{Be}$ age published by Johnson et al. (2008) from an erratic on a nearby island. In contrast to our bedrock samples this date may reflect a later retreat of the local ice front, giving evidence for an overall complex retreat history.

ii) If, on the other hand, the modeled rebound is stronger than the actual post-LGM isostatic compensation, surface exposure ages derived by a slower isostatic uplift would be about 8-9 ka and therefore similar to the ones we calculated in the first place. A potential early Holocene retreat history is mainly supported by the similarity to the regional pattern of glacial retreat derived from several offshore studies in Pine Island Bay (e.g. Hillenbrand et al., 2013; Larter et al., 2014).

To estimate the influence of either isostatic uplift or inheritance on the island samples, we calculated the amount of ${ }^{10} \mathrm{Be}$ produced within the sampled surfaces during their theoretic exhumation from below sea level (at depths of $\sim 436 \mathrm{~m}$ ) to their modern-day elevation, where $\sim 436 \mathrm{~m}$ depth equate to $5 \%$ of the local ${ }^{10} \mathrm{Be}$ production (at sea level $5.543 \mathrm{at} / \mathrm{g}^{*} \mathrm{yr}$ ). For the calculation we further used a density of $1.030 \mathrm{~g} / \mathrm{cm}^{3}$ (for sea water), and an attenuation length of $150 \mathrm{~g} / \mathrm{cm}^{2}$ as a mean value for Antarctic rocks (Brown et al., 1992; Brook et al., 1996). Finally, we used the mean local rebound rates of $0.63 \pm 0.04$ and $0.66 \pm 0.04 \mathrm{~cm} / \mathrm{yr}$ from Whitehouse et al. (2012a; 2012b, and personal communication). The results show that ${ }^{10} \mathrm{Be}$-concentration from exposure purely controlled by isostatic uplift would be approximately one half to one third of the measured concentration. So following possibility (i) above, if the modeled rebound rates are close to the actual conditions, there would be a component of varying degree of inherited ${ }^{10} \mathrm{Be}$ in all three samples. Applying multiple isotopes (e.g. Bierman et al., 1999; White et al., 2011) could resolve if, and how strongly, the samples are influenced by inheritance, which we could not do here due to limited sample material. However, if we look at the problem vice-versa and calculate/model rebound rates necessary to produce the measured amount of ${ }^{10} \mathrm{Be}$-concentration, we find rates 17-53\% lower than the mean modeled rebound rates from Whitehouse et al. (2012a; 2012b, and personal communication). Most striking here is the difference between outlier ISL-1 and sample ISL-2: To reach the amount of measured ${ }^{10} \mathrm{Be}$-concentration for sample ISL-1 it requires a rebound less than $53 \%$ of the mean modeled rates from Whitehouse et al. (2012a; 2012b, and personal communication), whereas a reduction of less than $17 \%$ would provide the measured ${ }^{10} \mathrm{Be}$-concentration in sample ISL- 2 at a calculated rebound rate of $0.52 \pm 0.05 \mathrm{~cm} / \mathrm{yr}$. This value in turn is close to the one for sample ISL-3, which has an inverse calculated rebound rate of $0.49 \pm 0.05 \mathrm{~cm} / \mathrm{yr}$; that is approximately $27 \%$ lower than the modeled rates (Whitehouse et al., 2012a, 2012b, and personal communication). The similar rebound-calculation results of ISL-2 and ISL-3 potentially suggest the isostatic rebound in Pine Island Bay may have been slower by about $17 \%$ than hitherto assumed by isostasy modeling only. Additionally, interpretation (ii) of our data supports and strengthens the case for potential nuclide inheritance in ISL-1. In the end, surface exposure ages for northern Pine Island Bay discussed in this study are $9.4 \pm 0.9 \mathrm{ka}$ and $8.1 \pm 0.8 \mathrm{ka}$, with a potential component of 'below-sea-level production', which is negligible because it is within the error.

\subsection{Kohler Range: simple ice-sheet modeling}

Based on glacier mechanics, glacial thinning and grounding-line retreat reshape the ice-sheet surface profile in a way that affects near-coastal areas earlier than inland surfaces (Schoof, 2007). Therefore areas close to the ice margin are affected equally by thinning and by retreat, whereas central regions are more strongly influenced by thinning (e.g. Todd et al., 2010). The Kohler Range samples show such an inverted age-elevation relationship, with the lower (and more coastal) sample yielding an older age. Taking into account a minimum age for grounding-line retreat from the Dotson Ice Shelf front (11.8 ka, Hillenbrand et al., 2013, Fig. 1), we hypothesize that the cosmogenic age pattern in the Kohler Range can be utilized to estimate a paleo-grounding-line position for this 
location. Therefore we applied a very basic ice-sheet model (Nye, 1952 ) in combination with an analytic solution (Benn and Hulton, 2010) to test whether a modeled ice-sheet surface profile is able to support this hypothesis, and gain further insights on the early Holocene grounding-line position in the Kohler Range area (for details see Appendix C). Despite its simplicity, Nye's model (based on the present grounding-line position and average basal shear of $70 \mathrm{kPa}$ ) closely fits the modern ice-sheet profile (Fig. 4). Now in order to match the paleo-profile defined by our age pattern, we varied the grounding-line towards the coast starting at the position of open-marine sedimentation (Smith et al., 2011). The solution that best fits our data requires a grounding-line located $100 \mathrm{~km}$ further inland from the current best estimate (Smith et al., 2011). This modeled paleo-position coincides with an underlying narrow passage, defined by the eastern and western Kohler Range (Fig. 4). A morphologic bottleneck which might have locally pinned the ice sheet during the early Holocene before it retreated $20 \mathrm{~km}$ further inland towards its modern (grounding-line) position (Rignot et al., 2011, Fig. 1).

Our modeled paleo-profile is consistent with the local geomorphology of the Kohler Range and surface exposure data, without contradicting the minimum age for grounding-line retreat obtained from sediment cores near the Dotson ice-shelf front (Smith et al., 2011). Nevertheless, we are aware that understanding the behavior of the grounding-line and proper modeling of the socalled 'transition zone' is highly complex. Therefore our simple approach shall serve only as a first indication for a combined lateral and vertical deglaciation history of the Kohler Range.

\section{Discussion}

The Kohler Range data show an inverse age-elevation relationship, with exposure ages from the lower altitude site, MI $(12.6 \pm 1.2 \mathrm{ka})$ being $\sim 4$ ka older than $\mathrm{BB}(8.6 \pm 0.8 \mathrm{ka})$, a site located farther inland and at higher altitude (Fig. 3). From a modern perspective this can be explained by the fact that the Kohler Range hosts two glacial systems: (i) Kohler Glacier and (ii) its tributary, Simmons Glacier (Fig. 3, inset). Thus the data appear to represent an individual thinning history for each glacial system. However, this explanation contradicts that neither of these glaciers existed during the LGM, at the time the area was covered by an ice cap that formed the earlier WAIS (in which models suggest that ice was about $800 \mathrm{~m}$ thicker; Whitehouse et al., 2012a). The present-day glaciers formed as a result of post-LGM ice-sheet retreat and therefore our data more likely represent the early Holocene deglaciation of the Kohler Range itself.

Most ice caps and sheets are characterized by a glacier slope that is steep at its outer margin and flattens off towards the center (Bennett and Glasser, 2009). As a result the combined effect of glacial thinning and grounding-line retreat is strongest at the margins (e.g. Schoof, 2007; Todd et al., 2010). This is coherent with the observation that the near-coast site (MI) yielded older ages than the inland site (BB). The $12.6 \pm 1.2 \mathrm{ka}$ exposure age for MI indicates that the ice sheet in the Kohler Range had thinned below about $\sim 459 \mathrm{~m}$ a.s.l. prior to the Holocene. Located $22 \mathrm{~km}$ further inland and at higher elevation $(\sim 735 \mathrm{~m})$, BB became ice-free about $4 \mathrm{ka}$ later, thus the ice was roughly $300 \mathrm{~m}$ thicker there then than it is today. Present-day ice surface elevation and exposure data from BB and MI suggest local long-term average thinning rates of $3.6 \pm 0.7$ and $3.0 \pm 0.3 \mathrm{~cm} / \mathrm{yr}$ since 8 and $12 \mathrm{ka}$, respectively. These rates are similar to the ones published for Smith Glacier on the eastern flank of the Kohler Range $(2.3 \pm 0.2 \mathrm{~cm} / \mathrm{yr}$ of minimum glacial thinning since the LGM; Johnson et al., 2008) and also fall within the range reported from western Marie Byrd Land $(2.5-9 \mathrm{~cm} / \mathrm{yr}$; Stone et al., 2003). The early Holocene inland-retreat rates also agree with those derived offshore from the marine record. Smith et al. (2011) documented open-water conditions at $11.4 \mathrm{ka}$ cal yrs BP (or 11.8 ka as recalculated by Hillenbrand et al., 2013) and showed that the front of the Dotson Ice Shelf retreated about $50 \mathrm{~km}$ since $13.8 \mathrm{ka}$, reaching close to its modern position during the early

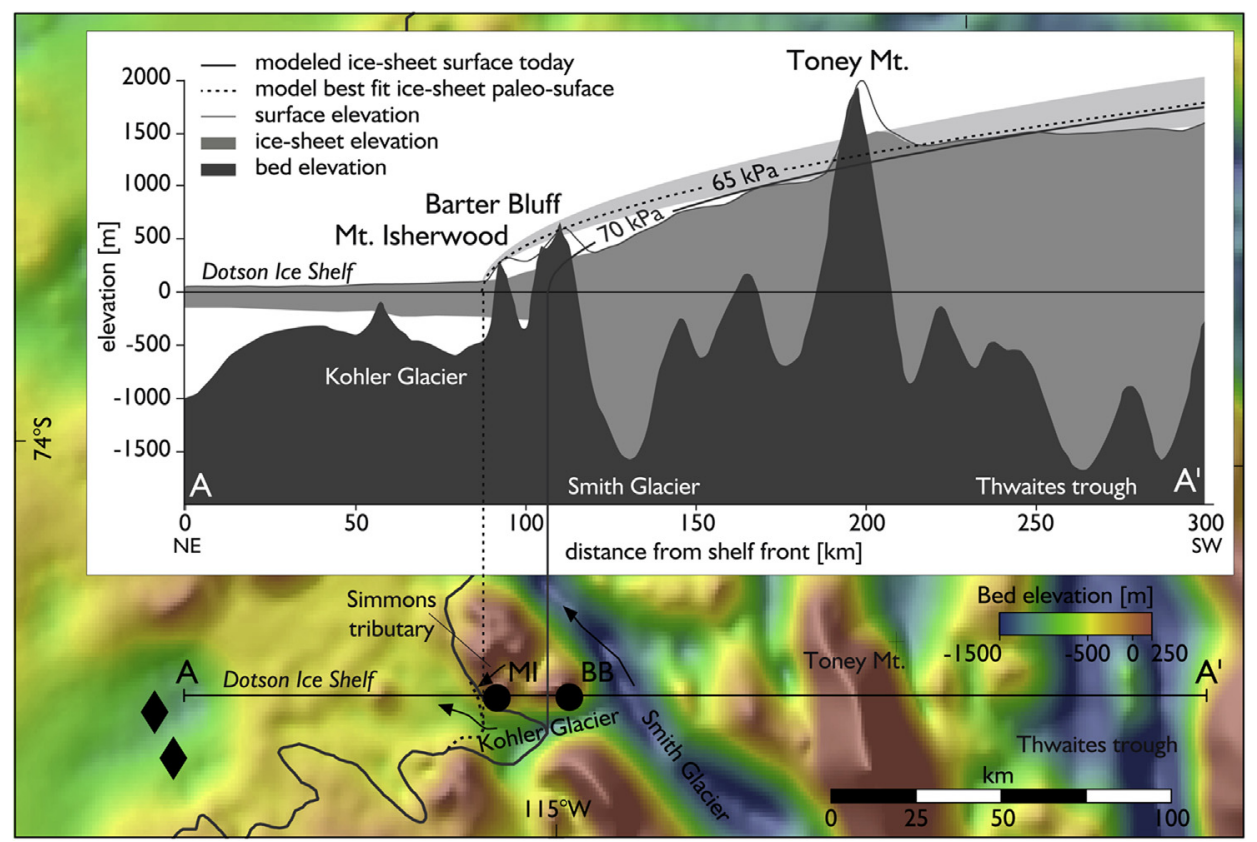

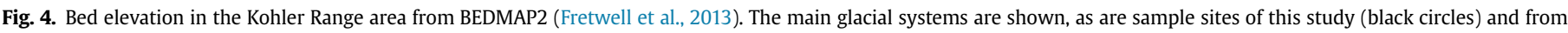

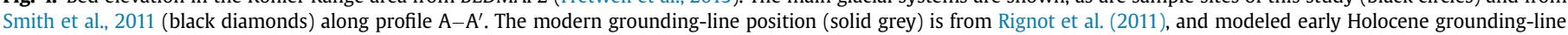

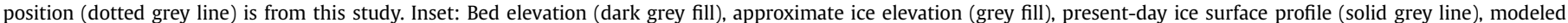

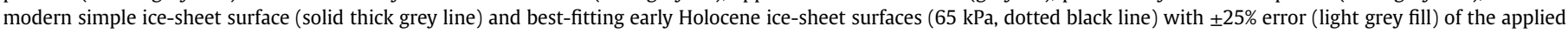
$70 \mathrm{kPa}$ modern average basal shear along profile A-A' (map). Surface and bed elevation data are from BEDMAP2 (Fretwell et al., 2013). 
Holocene. Hereby, our model analysis suggests that, in order to produce a simple ice-sheet surface that reflects the early Holocene age pattern of MI and BB the paleo-grounding line has to be positioned about $100 \mathrm{~km}$ inland from the current estimate based on the sediment core sites of Smith et al. (2011) (Fig. 4). The distance between our sample sites $(22 \mathrm{~km})$ and the difference in their surface exposure ages refer to an average maximum retreat rate of $\sim 5.3 \mathrm{~m} /$ yr. This is similar to the maximum average grounding-line retreat rate of $6.7 \mathrm{~m} / \mathrm{yr}$ since $11.8 \mathrm{ka}$ proposed for the Dotson ice shelf by Hillenbrand et al. (2013).

The outlier sample MI-3 is the only non-granitic erratic from the Kohler Range, which supports the possibility that its presence results from a different (earlier) retreat phase. There are only a few nunataks in the Kohler Range and the near hinterland, and none of them is known to consist of mylonitic bedrock. This implies a source upstream and deeper within the ice-covered West Antarctic hinterland.

The exposure ages of Pine Island Bay appear to reflect glacial retreat from (pre-)Holocene times to the modern configuration and show a disagreement to the modeled rebound rates for the area by at least 17\% (e.g. Whitehouse et al., 2012a, 2012b). The former is consistent with the suggestion that the Pine Island ice front had reached its modern-day position by the early Holocene (Larter et al., 2014, and references therein). The surface exposure age of $8.1 \pm 0.8 \mathrm{ka}$, close to Pine Island Trough (Fig. 1), is thus suggestive of a very rapid retreat of at least $80 \mathrm{~km}$ since that time (providing retreat rates of $8.5 \pm 1.6$ to $9.9 \pm 2.1 \mathrm{~m} / \mathrm{yr}$ ). Similar rapid thinning (of $\sim 1 \mathrm{~m} / \mathrm{yr}$ ) at $\sim 8 \mathrm{ka}$ is discussed for the adjacent Hudson Mts. along eastern Pine Island Bay by Johnson et al. (2014). Our data from the coast-proximal island may reflect an early post-LGM retreat phase across Pine Island Bay. However, this bedrock exposure age is about 7 ka older than a ${ }^{10} \mathrm{Be}$ age published by Johnson et al. (2008) from an erratic boulder of an island nearby. As the islands are located very close to the modern ice-sheet front, local ice advances are likely. Thus we agree with Johnson et al. (2008) that the erratic boulder, in relation to our bedrock samples, may have been deposited during a later episode of retreat of a local ice front in this area.

\section{Conclusion}

In summary, the ${ }^{10} \mathrm{Be}$ surface exposure data presented here suggest that the Amundsen Sea sector was affected by lateral and vertical glacial retreat in pre- to early Holocene times. We show that the ice-sheet in the Kohler Range had thinned by about $350 \mathrm{~m}$ since $12 \mathrm{ka}$, and the ice-shelf front in Pine Island Bay potentially retreated $\sim 80 \mathrm{~km}$ farther inland close to its modern position within the last $10 \mathrm{ka}$. The calculated average retreat rates of $8.5 \pm 1.6$ to $9.9 \pm 2.1 \mathrm{~m} / \mathrm{yr}$ for Pine Island Bay and $5.3 \pm 1.1 \mathrm{~m} / \mathrm{yr}$ for the Kohler Range from terrestrial data are similar to published Holocene maximum gradual retreat proposed by marine sediment cores.

In general, we find a close agreement between our results and the hypothesis that the post-LGM history was characterized by an overall retreat in the Amundsen Sea shelf area, and that this part of the WAIS had reached a configuration close to the modern day by early Holocene times. In addition, our exposure ages from central Pine Island Bay are not in line with published modeled rebound rates and suggest a local isostatic uplift slower by $17-27 \%$. Therefore more data is needed to better understand the isostatic compensation pattern.

The long-term average thinning rate calculated for the Kohler Range during the Holocene is $3.3 \pm 0.3 \mathrm{~cm} / \mathrm{yr}$, which is at least one order of magnitude lower than the thinning rates of $\sim 30 \mathrm{~cm} / \mathrm{yr}$ observed over the past two decades (Pritchard et al., 2012). A simple ice-sheet surface model suggests a local grounding-line position potentially closer to the coast than hitherto assumed from marine sediment data. The results of this study, although limited in number, are the first of their kind for the western Amundsen Sea sector, and together with our data from Pine Island Bay, they improve our understanding of the post-LGM history of eastern Marie Byrd Land and provide valuable constraints for future ice-sheet models.

\section{Acknowledgments}

We thank the captain and crew of RV Polarstern cruise ANTXXVI/3, the team from Heli Service International, J. Smith, I. MacNab (British Antarctic Survey), M. Scheinert and R. Rosenau (Dresden) for sampling assistance. For their help with the sample processing and analysis we acknowledge A. Toltz, A. Klügel (Bremen), P. Kubik (ETH Zürich), T. Dunai (Cologne), R. Hetzel and A. Niehaus (Münster). Special thanks go to P. Whitehouse (Durham) and A. Paul (MARUM, Bremen) for constructive discussions about ice-sheet modeling, and R. Larter for his comments on the manuscript. We furthermore thank G. Bromley and N. Glasser whose conducive reviews helped to improve the paper. This work was financially supported by the Deutsche Forschungsgemeinschaft (501100001659) (DFG) in the framework of the priority program 'Antarctic Research with comparative investigations in Arctic ice areas' through grant no. SP673/6-1, and forms part of the British Antarctic Survey programme 'Polar Science for Planet Earth', funded by the Natural Environment Research Council.

\section{Appendix A. Supplementary data}

Supplementary data related to this article can be found at http:// dx.doi.org/10.1016/j.quascirev.2014.05.010.

\section{References}

Balco, G., Stone, J.O., Lifton, N.A., Dunai, T.J., 2008. A complete and easily accessible means of calculating surface exposure ages or erosion rates from (10)Be and (26)Al measurements. Quat. Geochronol. 3, 174-195.

Bamber, J.L., Gomez-Dans, J.L., Griggs, J.A., 2009a. A new 1 km digital elevation model of the Antarctic derived from combined satellite radar and laser data part 1: data and methods. Cryosphere 3, 101-111.

Bamber, J.L., Riva, R.E.M., Vermeersen, B.L.A., LeBrocq, A.M., 2009b. Reassessment of the Potential Sea-Level Rise from a Collapse of the West Antarctic Ice Sheet. Science 324, 901-903.

Benn, D.I., Hulton, N.R.J., 2010. An Excel (TM) spreadsheet program for reconstructing the surface profile of former mountain glaciers and ice caps. Comput. Geosci.-UK 36, 605-610.

Bennett, M.M., Glasser, N.F., 2009. Glacial Geology: Ice Sheets and Landforms. Wiley.

Bierman, P.R., Marsella, K.A., Patterson, C., Davis, P.T., Caffee, M., 1999. Mid-Pleistocene cosmogenic minimum-age limits for pre-Wisconsinan glacial surfaces in southwestern Minnesota and southern Baffin Island: a multiple nuclide approach. Geomorphology 27, 25-39.

Bindschadler, R., Vornberger, P., Fleming, A., Fox, A., Mullins, J., Binnie, D. Paulsen, S.J., Granneman, B., Gorodetzky, D., 2008. The Landsat Image Mosaic of Antarctica. Remote Sens. Environ. 112, 4214-4226.

Bingham, R.G., Ferraccioli, F., King, E.C., Larter, R.D., Pritchard, H.D., Smith, A.M., Vaughan, D.G., 2012. Inland thinning of West Antarctic Ice Sheet steered along subglacial rifts. Nature 487, 468-471.

Brook, E.J., Brown, E.T., Kurz, M.D., Raisbeck, G.M., Yiou, F., 1996. An Antarctic perspective on in-situ cosmogenic nuclide production. Radiocarbon 38, 150

Brown, E.T., Brook, E.J., Raisbeck, G.M., Yiou, F., Kurz, M.D., 1992. Effective attenuation lengths of cosmic rays producing 10Be AND $26 \mathrm{Al}$ in quartz: implications for exposure age dating. Geophys. Res. Lett. 19, 369-372.

Cuffey, K.M., Paterson, W.S.B., 2010. The Physics of Glaciers. Elsevier Science.

Dunai, T.J., 2010. Cosmogenic Nuclides: Principles, Concepts and Applications in the Earth Surface Sciences. Cambridge University Press.

Favier, L., Durand, G., Cornford, S.L., Gudmundsson, G.H., Gagliardini, O., GilletChaulet, F., Zwinger, T., Payne, A.J., Le Brocq, A.M., 2014. Retreat of Pine Island Glacier controlled by marine ice-sheet instability. Nat. Clim. Chang. 2094, 1-5.

Fretwell, P., Pritchard, H.D., Vaughan, D.G., Bamber, J.L., Barrand, N.E., Bell, R. Bianchi, C., Bingham, R.G., Blankenship, D.D., Casassa, G., Catania, G., Callens, D., Conway, H., Cook, A.J., Corr, H.F.J., Damaske, D., Damm, V., Ferraccioli, F. Forsberg, R., Fujita, S., Gim, Y., Gogineni, P., Griggs, J.A., Hindmarsh, R.C.A., Holmlund, P., Holt, J.W., Jacobel, R.W., Jenkins, A., Jokat, W., Jordan, T., King, E.C., 
Kohler, J., Krabill, W., Riger-Kusk, M., Langley, K.A., Leitchenkov, G., Leuschen, C., Luyendyk, B.P., Matsuoka, K., Mouginot, J. Nitsche, F.O., Nogi, Y., Nost, O.A., Popov, S.V., Rignot, E., Rippin, D.M., Rivera, A., Roberts, J., Ross, N., Siegert, M.J. Smith, A.M., Steinhage, D., Studinger, M., Sun, B., Tinto, B.K., Welch, B.C., Wilson, D., Young, D.A., Xiangbin, C., Zirizzotti, A., 2013. Bedmap2: improved ice bed, surface and thickness datasets for Antarctica. Cryosphere 7, 375-393.

Gohl, K., Denk, A., Eagles, G., Wobbe, F., 2013a. Deciphering tectonic phases of the Amundsen Sea Embayment shelf, West Antarctica, from a magnetic anomaly grid. Tectonophysics 585, 113-123.

Gohl, K., Uenzelmann-Neben, G., Larter, R.D., Hillenbrand, C.-D., Hochmuth, K., Kalberg, T., Weigelt, E., Davy, B., Kuhn, G., Nitsche, F.O., 2013b. Seismic stratigraphic record of the Amundsen Sea Embayment shelf from pre-glacial to recent times: evidence for a dynamic West Antarctic Ice Sheet. Mar. Geol. 344 115-131.

Graham, A.G.C., Larter, R.D., Gohl, K., Dowdeswell, J.A., Hillenbrand, C.D., Smith, J.A., Evans, J., Kuhn, G., Deen, T., 2010. Flow and retreat of the Late Quaternary Pine Island-Thwaites palaeo-ice stream, West Antarctica. J. Geophys. Res. Earth 115.

Hillenbrand, C.D., Kuhn, G., Smith, J.A., Gohl, K., Graham, A.G.C., Larter, R.D. Klages, J.P., Downey, R., Moreton, S.G., Forwick, M., Vaughan, D.G., 2013 Grounding-line retreat of the West Antarctic Ice Sheet from inner Pine Island Bay. Geology 41, 35-38.

Johnson, J.S., Bentley, M.J., Gohl, K., 2008. First exposure ages from the Amundsen Sea Embayment, West Antarctica: the late quaternary context for recent thinning of Pine Island, Smith, and Pope Glaciers. Geology 36, 223-226.

Johnson, J.S., Bentley, M.J., Smith, J.A., Finkel, R.C., Rood, D.H., Gohl, K., Balco, G. Larter, R.D., Schaefer, J.M., 2014. Rapid Thinning of Pine Island Glacier in the Early Holocene. Science 343, 999-1001.

Joughin, I., Alley, R.B., 2011. Stability of the West Antarctic Ice Sheet in a warming world. Nat. Geosci. 4, 506-513.

Joughin, I., Smith, B.E., Holland, D.M., 2010. Sensitivity of 21st century sea level to ocean-induced thinning of Pine Island Glacier, Antarctica. Geophys. Res. Lett. 37.

Kirshner, A.E., Anderson, J.B., Jakobsson, M., O'Regan, M., Majewski, W., Nitsche, F.O. 2012. Post-LGM deglaciation in Pine Island Bay, West Antarctica. Quat. Sci. Rev. $38,11-26$.

Lal, D., 1991. Cosmic-Ray Labeling of Erosion Surfaces - Insitu Nuclide ProductionRates and Erosion Models. Earth Planet Sci. Lett. 104, 424-439.

Larter, R.D., Anderson, J.B., Graham, A.G.C., Gohl, K., Hillenbrand, C.-D., Jakobsson, M., Johnson, J.S., Kuhn, G., Nitsche, F.O., Smith, J.A., Witus, A.E., Bentley, M.J., Dowdeswell, J.A., Ehrmann, W., Klages, J.P., Lindow, J., Cofaigh, C.Ó., Spiegel, C. 2014. Reconstruction of changes in the Amundsen Sea and Bellingshausen Sea sector of the West Antarctic Ice Sheet since the Last Glacial Maximum. Quat. Sci. Rev. http://dx.doi.org/10.1016/j.quascirev.2013.10.016.

LeMasurier, W.E., 2008. Neogene extension and basin deepening in the West Antarctic rift inferred from comparisons with the East African rift and other analogs. Geology 36, 247-250.

Mackintosh, A., White, D., Fink, D., Gore, D.B., Pickard, J., Fanning, P.C., 2007. Exposure ages from mountain dipsticks in Mac. Robertson Land, East Antarctica, indicate little change in ice-sheet thickness since the Last Glacial Maximum. Geology 35, 551-554.

Mackintosh, A.N., Verleyen, E., O'Brien, P.E., White, D.A., Jones, R.S., McKay, R., Dunbar, R., Gore, D.B., Fink, D., Post, A.L., Miura, H., Leventer, A., Goodwin, I., Hodgson, D.A., Lilly, K., Crosta, X., Golledge, N.R., Wagner, B., Berg, S., van Ommen, T., Zwartz, D., Roberts, S.J., Vyverman, W., Masse, G., 2014. Retrea history of the East Antarctic Ice Sheet since the Last Glacial Maximum. Quat Sci. Rev. http://dx.doi.org/10.1016/j.quascirev.2013.07.024.
Mercer, J.H., 1978. West Antarctic Ice Sheet and $\mathrm{Co}_{2}$ Greenhouse Effect - Threat of Disaster. Nature 271, 321-325.

Nitsche, F.O., Gohl, K., Larter, R.D., Hillenbrand, C.D., Kuhn, G., Smith, J.A., Jacobs, S., Anderson, J.B., Jakobsson, M., 2013. Paleo ice flow and subglacial meltwater dynamics in Pine Island Bay, West Antarctica. Cryosphere 7, 249-262.

Nitsche, F.O., Jacobs, S.S., Larter, R.D., Gohl, K., 2007. Bathymetry of the Amundsen Sea continental shelf: implications for geology, oceanography, and glaciology. Geochem. Geophy. Geosy. 8.

Nye, J.F., 1952. A Method of Calculating the Thicknesses of the Ice-Sheets. Nature $169,529-530$

Pritchard, H.D., Arthern, R.J., Vaughan, D.G., Edwards, L.A., 2009. Extensive dynamic thinning on the margins of the Greenland and Antarctic ice sheets. Nature 461, $971-975$.

Pritchard, H.D., Ligtenberg, S.R.M., Fricker, H.A., Vaughan, D.G., van den Broeke, M.R., Padman, L., 2012. Antarctic ice-sheet loss driven by basal melting of ice shelves. Nature 484, 502-505.

Rignot, E., 2006. Changes in ice dynamics and mass balance of the Antarctic ice sheet. Philos. Trans. R. Soc. A 364, 1637-1655.

Rignot, E., 2008. Changes in West Antarctic ice stream dynamics observed with ALOS PALSAR data. Geophys. Res. Lett. 35.

Rignot, E., Bamber, J.L., Van Den Broeke, M.R., Davis, C., Li, Y.H., Van De Berg, W.J., Van Meijgaard, E., 2008. Recent Antarctic ice mass loss from radar interferometry and regional climate modelling. Nat. Geosci. 1, 106-110.

Rignot, E., Mouginot, J., Scheuchl, B., 2011. Antarctic grounding line mapping from differential satellite radar interferometry. Geophys. Res. Lett. 38.

Schoof, C., 2007. Ice sheet grounding line dynamics: steady states, stability, and hysteresis. J. Geophys, Res.-Earth 112.

Shepherd, A., Wingham, D., 2007. Recent Sea-Level Contributions of the Antarctic and Greenland Ice Sheets. Science 315, 1529-1532.

Shepherd, A., Wingham, D., Rignot, E., 2004. Warm ocean is eroding West Antarctic Ice Sheet. Geophys. Res. Lett. 31.

Smith, J.A., Hillenbrand, C.D., Kuhn, G., Larter, R.D., Graham, A.G.C., Ehrmann, W., Moreton, S.G., Forwick, M., 2011. Deglacial history of the West Antarctic Ice Sheet in the western Amundsen Sea Embayment. Quat. Sci. Rev. 30, 488-505.

SPRITE-Group, Boyer, C.G., 1992. The southern rim of the Pacific Ocean: preliminary geologic report of the Amundsen Sea-Bellingshausen Sea cruise of the Polar Sea. Antarct. J. U. S. A., 11-14.

Stone, J.O., 2000. Air pressure and cosmogenic isotope production. J. Geophys. Res. Sol Earth 105, 23753-23759.

Stone, J.O., Balco, G.A., Sugden, D.E., Caffee, M.W., Sass, L.C., Cowdery, S.G., Siddoway, C., 2003. Holocene deglaciation of Marie Byrd Land, West Antarctica. Science 299, 99-102.

Todd, C., Stone, J., Conway, H., Hall, B., Bromley, G., 2010. Late Quaternary evolution of Reedy Glacier, Antarctica. Quat. Sci. Rev. 29, 1328-1341.

White, D., Fulop, R.H., Bishop, P., Mackintosh, A., Cook, G., 2011. Can in-situ cosmogenic C-14 be used to assess the influence of clast recycling on exposure dating of ice retreat in Antarctica? Quat. Geochronol. 6, 289-294.

Whitehouse, P.L., Bentley, M.J., Le Brocq, A.M., 2012a. A deglacial model for Antarctica: geological constraints and glaciological modelling as a basis for a new model of Antarctic glacial isostatic adjustment. Quat. Sci. Rev. 32, 1-24.

Whitehouse, P.L, Bentley, MJ. Milne, G.A., King M.A., Thomas, I.D., 2012b. A new glacial isostatic adjustment model for Antarctica: calibrated and tested using observations of relative sea-level change and present-day uplift rates. Geophys. J. Int. 190, 1464-1482. 